Article

\title{
Recognizing and Acknowledging Worldview Diversity in the Inclusive Classroom
}

\author{
Janieta Bartz ${ }^{1, *}$ and Thomas Bartz ${ }^{2}$ \\ 1 Department of Social and Emotional Development in Rehabilitation and Education, TU Dortmund \\ University, 44221 Dortmund, Germany \\ 2 Department of German Language and Literature, TU Dortmund University, 44221 Dortmund, Germany; \\ thomas.bartz@tu-dortmund.de \\ * Correspondence: janieta.bartz@tu-dortmund.de
}

Received: 12 October 2018; Accepted: 2 November 2018; Published: 7 November 2018

check for updates

\begin{abstract}
In the context of the increasing migration into Germany that has taken place in recent years and German efforts to establish an inclusive school system, which enables learners from different religious, ethnic, language and social backgrounds with and without disabilities to participate, religious education has become a key topic for interdisciplinary discourse between theology, philosophy, and pedagogy in German schools. The following questions are of special interest: How can we manage diversity in inclusive classroom settings in general, and specifically: how can we do so with regard to worldview diversity? Does worldview diversity in schools exist, and if so, how can we recognize it in its plurality and complexity? How can we acknowledge different worldviews in the context of a changing inclusive school system? In this article, we would like to present the theoretical foundation, the research setting and the first findings of our ongoing pilot studies of worldview education at an inclusive German school. The experiments are part of a larger project context that is also described. The case study presented in this article, in which innovative language and machine learning technology was used for data analysis, illustrates the potential of inclusive methods and didactic concepts such as Universal Design for Learning, Learning in the Presence of the Other, and Reflexive Inclusion for inclusive worldview education in the context of a religiously pluralized and secularized society.
\end{abstract}

Keywords: inclusion; worldview education; universal design for learning; learning in the presence of the other; reflexive inclusion

\section{Introduction}

These days, religious education in German schools is a key topic for interdisciplinary discourse between theology, philosophy, and pedagogy. A greater religious and non-religious diversity can be observed in German classrooms today than in the middle of the 20th century when many Germans belonged to the Catholic or Protestant Church. In the context of secularism and syncretism, however, young people's religious and moral identities have become much more diverse [1]. There are various reasons for this. Apart from the increasing global pluralization in moral issues and the rapid secularization beginning in the 1960s [2,3], other important factors are the increasing migration of refugees to Germany that has taken place in recent years and German efforts to establish an inclusive school system. These developments result in a high degree of complexity including various levels of diversity, which have a huge impact on encounters between teachers, learners, and parents at school [4]. It may lead to conflicts and disagreements as well as to fruitful learning processes. Therefore, it is important for teachers to be able to recognize, analyze and acknowledge this diversity and its impact on teaching processes. However, especially in the context of inclusive schools, this is 
a challenge for everyone involved: How to manage diversity in inclusive schools and classrooms? How to acknowledge differences in the context of inclusive education? What methods are helpful for establishing successful inclusive learning processes? These are important questions both in the field of inclusive education as well as in the field of religious education in Germany.

At TU Dortmund University, these questions are being addressed within the scope of "DoProfil" (Dortmunder Profil für inklusionsorientierte Lehrer/-innenbildung_Dortmund profile for inclusion-oriented teacher education), an interdisciplinary project funded by the German Federal Ministry of Education and Research. In a subproject, we focus specifically on the level of religious, cultural and moral diversity, to which we will refer in the following as worldview diversity. In this article we present the theoretical foundation, the research setting and first findings of the project. Starting with an overview of the ongoing discussion on inclusion in Germany (Section 1.1), we then outline how we are tackling the resulting challenges (Section 1.3). In doing so, we draw on the principles of Universal Design for Learning [5] and Reflexive Inclusion [6] as well as on the didactics of Learning in the Presence of the Other [2,3], which we introduce as important sources in the preceding section (Section 1.2). In the main part, the article focuses on the methodology (Section 2) and the results (Section 3) of the case study, which we present and discuss (Section 4).

\subsection{Towards Inclusive Education in Germany}

The discussion about inclusive education in German schools revolves around several aspects. Many supporters of inclusive education focus on a moral perspective. For them, inclusive education is an element of participation and educational justice [7,8]. All learners in Germany should have the possibility to learn without having to bear disadvantages because of their social or personal backgrounds. In the past, learners with special needs in terms of their learning and personal abilities were sent to separate schools called Sonderschulen, i.e., schools providing special education. In these schools, teachers with special knowledge about learning differences were responsible for teaching learners in a particular way in order to meet their specific educational needs and help them to attend a regular school one day. Ultimately, however, many of these learners were not integrated into regular schools, with the result that they suffered from many disadvantages: longer journeys to school, living with stigmatism, lower job perspectives etc. Therefore, advocates of inclusive education ask for structures in schools in which every learner is welcome.

Inclusive education is a possibility to change your teaching perspective: it means that every single learner has a need for support; there are no 'special' children or young people with 'special' needs. One can say that every learner has a special need. The planning and conduct of inclusive lessons is characterized by diversity-sensitive diagnostics and support for all learners. This means, goal-differentiated teaching is not to be regarded as an exception, but as a general rule of inclusive education. The idea of collaborative classroom learning based on mutual recognition is enormously important from a social point of view, too. The idea of inclusion pursues the goal that one day it will no longer be necessary to speak of inclusion, since dealing with diversity has become a matter of course.

Over the past years, regular German schools started to integrate learners with special needs into their schools. As a consequence, teachers in German schools are now confronted with very different learners. Some have learning or other disabilities; others have just arrived in Germany a few months or years ago. Many German teachers have not been taught how to manage diverse levels of learning, cultural and personal abilities. For that reason, German schools and universities need good didactic concepts that help to manage diversity.

\subsection{Managing and Teaching (Worldview) Diversity: Theoretical Sources}

\subsubsection{Universal Design for Learning}

One of the most promising methods for managing diversity in the classroom is the Universal Design for Learning. This concept from the U.S. can provide orientation in the planning and implementation 
of inclusive teaching [5]. Based on the design concept of the same name [9], it highlights key points of a learning environment with as few barriers as possible, an environment which considers a variety of learning strategies and levels. The consideration of three basic principles ensures that learners can acquire knowledge and skills according to their individual requirements:

1. Offering various options for task processing (representation),

2. Design of active learning and expression possibilities (action and expression),

3. Enabling motivated learning (commitment).

From a religious and worldview didactic perspective, these principles can be concretized as follows: The principle of multiple forms of representation (1) corresponds to the complexity of many theological topics—including every day, children's and youth theology—or to the polyphony of biblical texts, which allows different emphases to be set. In addition, it makes sense to provide different editions of the Bible (e.g., in plain language, the German Elberfeld Bible or the German standard translation, etc.) or specialist information represented in various forms (text, video and/or audio versions), so that learners can choose an easier or more difficult access, depending on what suits them.

The principle of diverse forms of learning and expression (2) encourages the full exploitation of the spectrum of didactic approaches in religious education that is spread between the poles of cognition, performance and denomination. This principle allows learners to try themselves out and find adequate learning paths and forms of expression: Bibliodrama, bibliology, photo stories, role play, station or project work, creative writing etc.

Finally, the focus on commitment (3) recalls the serving-diaconal-function of religious education. learners should find themselves in confrontation with the transcendent, i.e., develop a (religious) identity. Without the willingness to really engage in the religious learning process, this cannot succeed. This willingness is promoted by guided work and the conscious integration of the individual personality of each learner in the teacher's counselling and reflection on learning outcomes.

\subsubsection{Reflective Inclusion}

The idea of intervention in the context of worldview diversity is important for teacher education at universities, too. Inclusive education succeeds above all through reflection by all those who are involved in teaching processes. Starting from the concept of reflective inclusion, the project described in this article addresses reflective and difference-sensitive teacher education. The professional orientation of teachers is of special importance for the pedagogical implementation of inclusion. In particular, this is underpinned by the approach of Reflective Inclusion [6], which understands difference as a product of social interactions in which (dis)advantages are inscribed. Such an understanding requires a specific mode of reflection that "comprises a permanent reflection on the individual consequences and structural conditions of one's own actions" [10]. Being already generally discussed as an important dimension of professionalism for teacher education, (self-)reflection is thus of significant importance for inclusive teacher education as well. Such an approach involves the challenge of reflecting on school practice with regard to the (re)production and processing of differences concerning worldview diversity as well as illuminating processes of stereotyping and maturation.

\subsubsection{Worldview Education: Learning in the Presence of the Other}

Worldview education should help learners to become aware of their similarities and strengthen their common values. At the same time, it is important that learners also recognize that there are many special features that need to be understood with regard to the multitude of personal and organized worldviews. This requires a special culture of encounter and learning [11]. Based on theological and anthropological optimism [12,13] (on "Religious Pedagogy of Hope"), the concept of Learning in the Presence of the Religious Other is based on the idea that a safe space can be created in learning 
environments that are sensitive to worldview diversity, where learners meet in their so-being, perceive their differences and use this perception to sharpen their own personal worldview concepts.

Personal worldviews [14] are generally not systematically or consistently coherent but allow the individual more or less certain answers to existential questions or a meaningful narration for his or her own life. They are derived from various sources: from the broad traditional and organized socio-political, religious, and cultural institutional systems of norms and values as well as from the (personal) worldviews of other individuals. Wherever superordinate action-guiding ideals, values or principles (so-called "broad moralities") are conveyed in organized or spontaneous learning situations, they can influence or expand the personal worldviews of the participants-not only in religious settings, but also in political or cultural teaching/learning contexts. Depending on the nature of the religious or world-oriented teaching processes in relation to the mode (didactic dimension) and possibility (pedagogical dimension) of personal engagement with the available worldviews as well as the type of theological or ideological discourse initiated and the underlying relationship (discursive dimension), different forms of interreligious or transcultural learning arise.

If worldviews emerge from the teaching discourse, e.g., as worldviews of the majority society or a certain group, or if they are reported by an authority on the basis of their power of interpretation, this encounter leads to a "learning about" [3], i.e., learning about a religion or a worldview concept. Differences are imparted objectively and initially without starting points for a constructive transformation. The communication of different worldviews level with the face allows a "learning from" [3], i.e., learning from a religion or ideological concept. The learners become partners, who reflect on their personal worldviews against the background of the differences that have come to light and who are able to relate aspects of personal and foreign worldviews to one another. This contributes to an internal differentiation of individual ideological concepts of norms and values. Finally, if teachers and learners dispose of their personal worldviews within the framework of an existential theological or ideological discourse conducted in an atmosphere of mutual trust, this permits a mutual immersion in the worlds of faith and narratives of the respective other, a "learning in/through" [3]. Such a discourse, which is comparable to a trusting conversation among friends, has an effect that is going beyond the differentiation and consolidation of fragmentary or inconsistent theological or ideological concepts. The hypothesis is that anyone who entrusts himself/herself entirely to a friend in his/her vulnerability also adopts the friend's personal concept of norms and values without, however, giving up his/her own. In a sincere encounter with the other, (post-)identitarian worldviews can thus emerge which appear to be sustainable sources for norms and values that guide action (broad moralities) with a view to a transcultural society.

What revision processes personal worldviews undergo in the presence of the other, how they are composed in detail and how their composition changes during the revision processes is a largely unanswered research question. It is to be expected, however, that the personal concepts will gain coherence and consistency and, in particular, will be adjusted with regard to those aspects that have been adopted unquestioningly as settings or commonplaces of a primary reference group or society, as prejudices, as superstition, etc. and do not stand up to critical reasoning. In this manner, the existential discourse in the presence of the other is an essential resource for synchronizing clashing worldviews. Above all, everyone participating in this discourse can convincingly contribute those aspects of his or her personal worldview that he or she has understood. In contrast, the influence of religious, cultural, or political authorities and the organized worldviews transported by them will be reduced.

\subsection{What We Do: Recognizing and Acknowledging Worldview Diversity in the Inclusive Classroom}

In our project, we closely cooperate with the inclusive Münsterlandschule in Tilbeck (near Münster, NRW, Germany), in order to establish and evaluate religious or worldview education (see Section 1.2.3) in a learning environment with a universal design (see Section 1.2.1). We accompany a heterogeneous class of 26 learners, aged between 17 and 19 years with different ethnic and religious backgrounds, who deal with different perspectives on the future within the framework of a class project entitled "Our School of the Future". The project was conducted over a period of 15 weeks and lessons took 
place in several blocks on two to three afternoons each week. These were interdisciplinary lessons in history, German, religion and art. At the beginning, the learners prepared an interesting research question on a future topic, which they developed further on an empirical and interdisciplinary basis. During their learning process they were advised and accompanied by their teachers and a research assistant of TU Dortmund University. The learning opportunities were intended to encourage learners to pursue their learning activities in a guided, yet self-controlled and active manner. At the end of the class project and research-based learning period, the learners prepared a project report on their research findings and a reflection of their results.

In order to create reflection events in the sense of Reflective Inclusion (see Section 1.2.2), the data collected at the inclusive Münsterlandschule were evaluated and discussed in seminars at TU Dortmund University. The results of these data-based discussions were then recommunicated to the teachers and learners creating a meta-level of reflection about worldview diversity.

In the case study presented below, we followed up on the question how personal worldviews and their development can be identified and analyzed within the inclusive learning environment described above in an efficient way. Which methodology is suitable for analyzing the complex textual and conversational data of learners and students at a reasonable expenditure of time? These were the questions that led us to the case study described below, which we conducted using an innovative technology-based approach, focusing on the following subordinate research questions that correspond to the overarching project goals:

1. What are the subjective narratives that learners use in order to understand and present themselves and their individual personalized worldviews?

2. What are the socio-cultural and religious narratives of our societies (organized worldviews) that they thereby refer to?

3. How can these narratives be analyzed and described efficiently?

\section{Materials and Methods}

The project reports of three 11th grade learners of the above-mentioned Münsterlandschule-a total of approx. 5000 words-provided the basis for the case study described in the following. Moreover, we also analyzed a much larger database of reference texts as possible sources of organized worldviews (see below). For the data analysis we have used an innovative approach based on language technology and machine learning. We have automated the manual steps of topic analysis that are normally required for a content analysis [15], which allows us to be more objective on the one hand and, on the other, to analyze larger amounts of data. This, in turn, should enhance the reliability and accuracy of the research results. However, the initial aim of the case study presented in this article was to provide a proof-of-concept for the proposed approach of analyzing.

In order to uncover not only the learners' individual personalized worldviews but also the superordinate organized worldviews to which these refer (see Section 1.2.3), we chose a two-stage procedure. The automatic identification of topic expressions in the available data plays a central role here. In the first step, we analyzed the personalized worldviews, which can be understood as identity-forming narratives, using an automatic linguistic method for co-reference analysis [16]. This method allows for the identification of narrative strands (thematic chains, so-called co-references) established by thematic expressions, which help to linguistically create a scenic imaginary space and an action taking place within it. In a second step, we selected potential reference texts on the dominant topics identified in the previous analysis, which convey possible superordinate organized worldviews that are connected with the learners' narratives. This selection of texts reflects our hypothesis according to which organized worldviews can be found in the learners' narratives. In a last step, we applied the Latent Dirichlet Allocation method [17] to the selected digital full texts and the learners' project reports. This method identifies and sorts the topics present in a text corpus and clusters the texts according to thematic similarity. If the reference texts and project reports were assigned to different 
thematic clusters, our hypothesis would be falsified. If common underlying topics and thematic clusters emerged for reference texts and project reports, our hypothesis would be verified. In the following, we will elaborate in more detail on the fundamentals of this procedure, i.e., the concept of linguistic topics and narratives (Section 2.1) as well as the automatic procedures mentioned above (Sections 2.2 and 2.3).

\subsection{Linguistic Topic and Narrative Concept}

From a linguistic point of view, topics are the subjects (facts, processes, things, etc.) about which something is said in a text or conversation [18]. To this end, they are repeatedly mentioned in the text or conversation by nouns, pronouns and other reference expressions and thus remembered by readers or listeners. Topics can be explicitly introduced, changed or further developed through certain formulation patterns or constructions. The way in which topics are linked and further developed in a text or conversation is specific to different text patterns. The text pattern of narration is characterized, among other things, by the fact that new information is continuously delivered on a chronological axis to constantly continued topics, whereby actions and developments as well as surprising twists can be staged [19]. Example (1) shows the constant continuation of the topics "Education" (T1, partly continued via the subtopics T1.1 and T1.2: "Knowledge", T1.3: "Experience" and T1.4: "Political and Ethical Ideas"), "School" (T2, partly continued via the subtopics T2.1: "Primary School" and T2.2: "Grammar School") and "Children" (T3).

(1) Bildung ${ }^{\mathrm{T} 1}$ gab es schon in der Steinzeit, als die ersten Menschen das Wissen ${ }^{\mathrm{T} 1.1}$ an die nachfolgenden Generationen weitergegeben haben. Es gibt $\underline{\operatorname{sie}}^{\mathrm{T} 1}$ also eigentlich schon seit ca. zweihunderttausend Jahren. $\underline{\text { Schulen }}^{\mathrm{T} 2}$, an $\underline{\text { denen }}^{\mathrm{T} 2}$ Lehrer Kentnisse ${ }^{\mathrm{T} 1.2}$ und Erfahrungen $^{\mathrm{T} 1.3}$ weitergegeben haben, sind aber viel später entstanden. Die ältesten Schulen ${ }^{\mathrm{T} 2}$ gab es vor viertausend Jahren in Ägypten. Kinder ${ }^{\mathrm{T} 3}$ lernten $\underline{\text { dort }}^{\mathrm{T} 2}$ einen Bestand an Wissen ${ }^{\mathrm{T} 1.1}$ und politische und ethische Vorstellungen ${ }^{\mathrm{T} 1.4}$ kennen. Nach einer Grundschule ${ }^{\mathrm{T} 2.1}$ konnten die $\underline{\text { Kinder }}^{\mathrm{T} 3}$ auf die ersten Gymnasien ${ }^{\mathrm{T} 2.2}$ gehen.

Education $^{T 1}$ already existed in the Stone Age, when the first people passed on the knowledge $e^{T 1.1}$ to the following generations. It ${ }^{T 1}$ has actually existed for about two hundred thousand years. However, $\underline{\text { schools }}^{T 2}$ $\underline{\text { where }}^{T 2}$ teachers have passed on their knowledge ${ }^{T 1.2}$ and experience ${ }^{T 1.3}$ came into being much later. The oldest schools ${ }^{T 2}$ existed in Egypt four thousand years ago. There ${ }^{T 2}$, children ${ }^{T 3}$ got to know a stock of knowledge $^{T 1.1}$ and political and ethical ideas ${ }^{T 1.4}$. After primary school ${ }^{T 2.1}$, the children ${ }^{T 3}$ could go to the first grammar schools ${ }^{T 2.2}$.

\subsection{Automatic co-Reference Analysis}

Automatic co-reference analysis is a computational linguistic method that facilitates the automatic detection of topics and their continuation in the course of a text as described in Section 2.1. This is considered to be a major challenge, especially with regard to the resolution of pronoun references. These references are often underspecified and can only be resolved by the semantics of the context. The analysis method we have chosen takes these into account via word occurrences in the context of pronouns that are typical for the respective reference expressions. The procedure is state-of-the-art. It currently offers the highest possible accuracy [16].

\subsection{Latent Dirichlet Allocation}

Latent Dirichlet Allocation is a machine learning method used to classify texts by topics. The procedure is based on the idea that the topics of a text result from the distribution of words in the text. Accordingly, each word of a text can be assigned to a (latent) topic, which in turn is represented by certain very frequent text words (e.g., "Development", "Pedagogy", "Education" vs. "School”, "Education system" vs. "Skills", "Maturity" etc.; see Section 3.2). The purpose of the procedure is to automatically optimize 
the allocation (Dirichlet distribution) of the text words to the topics in such a manner that the topics explain the text content in the best possible way [17].

\section{Results}

In this chapter, we present the results of our case study. First, we will take a look at the results of the analysis of personalized worldviews in the learner data (Section 3.1). Then we explain the identified interrelations to overarching organized worldviews (Section 3.2). Thirdly, we review the quality of the automatic procedures (Section 3.3).

\subsection{Personalized Worldviews}

The following table (Table 1) shows the results of the co-reference analysis conducted on the learners' project reports. The topics listed are those that were mentioned in the reports with an above-average frequency. The value specified in column 1 ("Token no.") identifies the text passage where the topic was first introduced (" $\mathrm{t} 361$ " means the 361st text word). Low token numbers indicate an early mention in the text, high token numbers indicate a late one. The value in column 3 ("Salience") indicates the relative frequency with which a topic is re-introduced in the text. High values in this column indicate central topics, which are usually repeated over the entire course of the text.

Table 1. Results of the co-reference analysis on the learners' project reports: main topics.

\begin{tabular}{ccc}
\hline Token No. & Topic & Salience \\
\hline t361 & Schule School & 0.129 \\
t380 & Bildung Education & 0.111 \\
t394 & Mensch Human & 0.124 \\
t415 & Mittelalter Middle Ages & 0.027 \\
t422 & Lehrer Teacher & 0.124 \\
t484 & Kind Child & 0.124 \\
t615 & Kirche Church & 0.022 \\
t1070 & Jugendliche Adolescents & 0.124 \\
t1077 & Gesellschaft Society & 0.027 \\
t1126 & Meinung Point of view & 0.022 \\
t1135 & Arbeit Work & 0.120 \\
t2022 & Zusammenleben Life together & 0.040 \\
t2038 & Zukunft Future & 0.058 \\
t2077 & Welt World & 0.098 \\
t2510 & Grünflächen Green areas & 0.098 \\
t2576 & Technik Technology & 0.062 \\
t2657 & Umwelt Environment & 0.098 \\
t4323 & iPad & 0.062 \\
\hline
\end{tabular}

The main topics identified make it easy to summarize the narratives contained in the learners' project reports: Not surprisingly, the main topics are "School", "Education", "Teacher" and "Children" /"Adolescents", which are directly derived from the project theme ("Our School of the Future"). What is interesting, however, is the early thematization of the humanistic ideal of education ("Human") and the role of the church for the schools of the Middle Ages ("Middle Ages"), to which the learners first refer. Only then a reference is made to the socializing function of schools ("Society", "Point of view", "Life together"), but also to the purpose of education for the working world (in the present). From the learners' point of view, the school of the future is characterized not only by a balanced relationship between humanistic education and training for a later employment, but also by a balanced relationship between innovative technology ("Technology", "iPad") and ecology ("Ecology", "Green areas") and by an increasing internationalization ("World"). 
In the following, some excerpts from the learners' project reports are presented as examples. These excerpts illustrate the narratives outlined above. Among other topics, first two excerpts (2), (3) deal with the influence of the Christian churches on the development of the education system:

(2) Viel von der Bildung wurde auch von der Kirche übernommen. In Klöstern oder Pfarrschulen wurden auch Lehrer ausgebildet. Die Reformatoren wollten dann nach einigen Jahren durchsetzten, das es Bildung für alle gibt, für Jugend und Mädchen, Reiche und Arme. Dies wurde durch die Gründung von Städten und durch den Buchdruck begünstigt.

Much of the education was also taken over by the church. Teachers were also trained in monasteries or parish schools. After a few years, the Reformers wanted education for all, for boys and girls, rich and poor. This was fostered by the founding of cities and by book printing.

(3) Noch heute sagt z.B. die evangelische Kirche in Deutschland, das die schulische Bildung und Erziehung von Kindern und Jugendlichen eine der wichtigsten Aufgaben in unserer Gesellschaft ist. Schulen müssen bereit sein, die Schüler auf eine Vielfalt von Lebenslagen vorzubereiten und den Schülern bei der Persönlichkeitsentwicklung und dem Prozess des Aufwachsens zu helfen. Sie muss sich auch auf Migration, Multikulturalität und mehrere Religionen einlassen. Schule soll nicht nur ein Ort des Lernens, sondern auch ein Ort des gemeinsamen Lebens sein. Man verbringt ja einen sehr großen Teil seines Lebens in der Schule, etwa zwei Drittel des Tages. Da sollte man sich auch wohlfühlen.

Even today, for example, the Protestant Church in Germany says that the education of children and young people at school is one of the most important tasks in our society. Schools must be ready to prepare students for a variety of situations and help them develop their personalities and grow up. They also have to engage with migration, multiculturalism and several religions. School should not only be a place of learning, but also a place of living together. You spend a very large part of your life at school, about two thirds of the day. You should feel comfortable there, too.

This feeling of well-being should be achieved in schools through innovative communication technology on the one hand, and through a pleasant ecological learning environment on the other (4), (5):

(4) Lernen ist in Zukunft stärker durch digitale Medien geprägt. Du hast keine Schultasche mehr, sondern dein Ipad und da sind alle Lernsachen drauf. Mann muss aber aufpassen, dass die Technik nur als Hilfsmittel genutzt wird und die Lehrkraft nicht vollständig ersetzt. Es gibt schon Kitas, in denen Ipads zur Dokumentation benutzt werden. Kinder können zwischendurch Fotos machen und sich diese später zusammen mit ihren Eltern anschauen oder besprechen.

In the future, learning will be more strongly influenced by digital media. You don't have a schoolbag anymore, you have your iPad and all your learning things are on it. But you have to be careful that the technique is only used as a tool and does not completely replace the teacher. There are already daycare centers in which iPads are used for documentation. Children can take photos in between and look at them later together with their parents or discuss them.

(5) Es kann interessant sein, in und von der Natur zu lernen. Wir sollten vielmehr im Grün und mit dem Grün lernen. In meiner Traumvorstellung wären Grünflächen um die Schule herum mit Bächen und Bäumen. Die Schule wird zum Lebensraum auch durch eine einladende Architektur. Beispielsweise könnte man den Boden mit Teppich auslegen und die Wände farbenfroh gestalten.

It can be interesting to learn in and from nature. We should rather learn in the green and with the green. My dream would be green spaces around the school with streams and trees. The school also becomes a living space through its inviting architecture. For example, you could cover the floor with carpet and make the walls colorful.

The following excerpts (6), (7) illustrate the relationship between the professional angle and the personal orientation of education: 
(6) Beim Thema Arbeit ist auch die Frage wichtig: Warum arbeitet man überhaupt? Man kann arbeiten, um Geld zu verdienen, oder Arbeiten, weil damit ein bestimmter Sinn verbunden ist. Zum Beispiel backt der Bäcker einerseits, um sein Geld zu verdienen, andererseits aber auch, um andere Menschen satt zu machen. Wenn jeder nur arbeitet, um Geld zu verdienen, entwickelt sich daraus eine egoistische Gesellschaft. Dann gibt es keine Liebe oder Wärme in der Gesellschaft mehr.

When it comes to work, the question is also important: Why work at all? You can work to earn money, or work because it has a certain meaning. For example, the baker bakes to earn money on the one hand, but also to feed other people. If everyone works just to make money, society becomes a selfish one. Then there will be no more love or warmth in society.

(7) Ich bin zu dem Entschluss gekommen, dass in der Schule die Persönlichkeitsentwicklung in Zukunft deutlich in den Vordergrund rücken wird. Kinder sind durch den medialen Umschwung vielfach in einer seperaten Welt unterwegs. In Schulen muss deshalb das Kommunikative untereinander gefördert werden. Ich habe selbst kleine Kinder im Fußball trainiert. Früher saßen wir in der Halle und haben uns zwischen den Spielen unterhalten. Heute sitzen die Kinder da und machen mit Snapchatfiltern Fotos. Der Kontakt mit den Lehrpersonen ist vor allem deshalb wichtig für die Persönlichkeitsentwicklung, weil man sich andauernd in dieser separaten digitalen Welt bewegt.

I have come to the conclusion that personality development will become much more important at school in the future. Due to the changes in the media, children often live in a separate world. In schools, therefore, the communication with each other must be promoted. I trained small children in football myself. We used to sit in the hall and talk between games. Today the children sit there and take photos with Snapchat filters. Contact with teachers is particularly important for personal development because one is constantly living in this separate digital world.

\subsection{Organized Worldviews}

We also investigated the potential sources of the personalized worldviews described above in an automated manner. The procedure used for this essentially resulted in two clusters of thematically uniform reference texts, each of which also contains the learners' project reports. The following two tables (Tables 2 and 3) show the topics that are common to all texts in one cluster. The value in the second table column ("Probability") indicates the prognostic relevance of a text topic for its assignment to the corresponding cluster.

Table 2. Results of the Latent Dirichlet Allocation clustering on the learners' project reports and a choice of potential reference texts: cluster $1^{1}$.

\begin{tabular}{cc}
\hline Common Topics & Probability \\
\hline Entwicklung Development & 0.023 \\
Pädagogik Pedagogy & 0.018 \\
Erziehung Education & 0.017 \\
\hline Schule School & 0.041 \\
Bildungssystem Education system & 0.002 \\
\hline Kinder Children & 0.039 \\
Individualität Individuality & 0.014 \\
\hline Fähigkeiten Skills & 0.019 \\
Allgemeinbildung General education & 0.006 \\
Mündigkeit Maturity & 0.005 \\
\hline
\end{tabular}

${ }^{1}$ Reference texts: Wilhelm von Humboldt (1793): Theorie der Bildung des Menschen Theory of Human Education; Johann Heinrich Pestalozzi (1820): Wie Gertrud ihre Kinder lehrt How Gertrud Teaches her Children; Maria Montessori (1923): Die Selbsterziehung des Kindes the Self-Education of the Child. 
Table 3. Results of the Latent Dirichlet Allocation clustering on the learners' project reports and a choice of potential reference texts: cluster $2^{1}$.

\begin{tabular}{cc}
\hline Common Topics & Probability \\
\hline Mensch Human & 0.002 \\
Mann Man & 0.001 \\
Frau Woman & 0.001 \\
\hline Grün Green & 0.010 \\
Pflanzen Plants & 0.008 \\
\hline Erkenntnis Cognition & 0.002 \\
Lernen Learning & 0.001 \\
\hline Garten Garden & 0.009 \\
Fläche Area & 0.004 \\
Boden Ground & 0.003
\end{tabular}

${ }^{1}$ Reference texts: The Bible (standard translation): Gen 2,4b-25 (The Paradise). The Quran (Bubenheim \& Elyas 1980 translation): Suras $2 ; 7 ; 9 ; 13 ; 18 ; 23 ; 47 ; 52 ; 54 ; 56 ; 75$.

The topics of the first cluster (reference texts by Humboldt, Pestalozzi and Montessori; Table 2) all relate to the field of education theories ("Development", "Pedagogy", "Education") or the school and education system. The focus on children and their individuality ("Children", "Individuality") as well as on their skills and important educational goals ("General education", "Maturity") also fits in. Those reference texts (the Bible, the Quran; Table 3) that we regard as sources of religious ideas of paradise are significantly different. It is interesting that the paradise concepts conveyed in the Bible and the Quran, which also occur in the learners' project reports, do not differ thematically to an extent that would justify an assignment to different clusters.

In other words, we can now assume that the learners in our experimental group derive their individual personalized worldviews from organized worldviews that differ little in content, even though the origin and sources of these worldviews differ. We see these results as a positive confirmation of our approach of recognizing and acknowledging worldview diversity in the inclusive classroom, where it is important to emphasize and strengthen the similarities in all apparent differences.

\subsection{Quality of the Automatic Procedures}

Our choice of automatic linguistic and machine learning methods has enabled us to obtain meaningful results regarding our research questions formulated above. According to their own studies, the developers of these methods assume an accuracy of $80-85 \%$ for the co-reference analysis method [16] and 85-95\% for the Latent Dirichlet Allocation method [17], respectively. Although the tools represent the current state of the art with these values, this is not sufficient for many linguistic applications. However, with regard to cases such as ours, we consider the procedures to be adequate. The automatic procedures have enabled us to evaluate a larger amount of text material in a structured manner with justifiable time expenditure, even within the framework of a qualitative research design. Once an automatic analysis procedure has been set up, it only takes a few minutes to complete. In addition, the quantity of material to be evaluated can be scaled considerably without significant additional effort. Another major advantage of automatic analysis is its reproducibility. Further studies involving the same tools and data can be expected to produce the same results.

\section{Discussion and Conclusions}

The results of the case study are instructive in four different ways with regard to the research background outlined in the first section and the questions raised in this broader context:

1. with regard to Universal Design for Learning as a framework that allows learners with different learning requirements to work intensively on a common topic (see Section 1.2.1).

2. in view of the emerging worldview diversity on a seemingly neutral topic (see Section 3.1). 
3. with regard to the possibility of exchanging worldview concepts in the presence of the other in a safe space while learning about, from and with each other (see Section 1.2.3).

4. in view of the importance of a Reflective Inclusion approach in teacher education (see Section 1.2.2).

In the following, we finally will summarize and discuss these questions against the backdrop of the study conducted.

\subsection{The Universal Design for Learning as an Activating Methodological Framework in Inclusive (Worldview) Education}

In view of the relatively broad theme of the project described above, "Our School of the Future", the level of profundity with which the learners have worked on this theme is remarkable. The learners not only developed a well thought-out plan for a good future school, including its architecture, equipment, pedagogical approach and function in society, they also took into account the history of the school system and the positions of important influential persons and institutions (see Section 3.1). Even though the effectiveness of the Universal Design for Learning framework in interaction with the heterogeneous learning group under investigation was not examined in an experimental manner, it can be ruled out that the learning success was spoiled by the inclusive learning environment. On the contrary, the learners succeeded in bundling the diversity of perspectives into a dense working result.

\subsection{Worldview Diversity as a Standard in (Inculsive) Education}

At first glance, the topic "Our School of the Future" is not necessarily dependent on religious, political or other worldviews. In this sense, it seems to leave room for-e.g., with regard to design and equipment-seemingly neutral concepts that may be discussed controversially in questions of taste, but not in questions of worldview. The results of the learning project show that learners can hardly avoid worldview questions when topics are discussed genuinely. Be it the question of general-, labor market-, or personality-oriented education, the question of the roles of the state and the church in education, the question of the purpose of work in life, the question of benefits and burdens of new technologies or even the question of how the ideal school building and its surroundings are to be designed-none of these questions can be seen as naive (see Section 3.1). The (automatic) intertextual analysis showed that the learners' school design concepts obviously incorporate ideas that refer to religious paradise visions of Christianity and Islam (see Section 3.2). These observations prove van der Kooij's thesis that education considering rules, values, morals, or politics in the broadest sense cannot be viewed in an ideologically neutral way [14]. In the context of a secularized society these values can either lead to conflicts and exclusion or to peaceful and enriching encounters empowered by inclusive worldview education.

The results indicate that worldview diversity certainly has an influence on teaching in inclusive classrooms. A heterogeneous learning group brings heterogeneous personal worldviews with it, referring to parts of larger overarching organized worldviews. Social, religious and cultural backgrounds of both teachers and learners unconsciously influence the subterranean learning process and must be taken into consideration when planning and conducting lessons.

\subsection{Inclusive Worldview Education as a Safe Space for Learning in the Presence of the Other}

If we, like van der Kooij [14], assume worldview diversity as the standard case, the question arises what a discourse about worldview questions should look like in inclusive education and how it can be ensured to be objective and to let each position come into its own. There is no doubt that worldview diversity has an influence on teaching togetherness and that teachers should be aware of this.

This is where the concept of Learning in the Presence of the Other (see Section 1.2.3) comes into play. If a safe space can be created in learning environments that are sensitive to worldview diversity, inclusive worldview education can help to resolve conflicts between students, parents or teachers. In doing so, the three perspectives or intensities of worldview learning must be taken into account, which we would like to address again at this point [3]: If there are no starting points for a constructive 
transformation, differences can at least be imparted objectively in the mode of "learning about". The communication of the different worldviews at eye level allows a "learning from" process in the course of which personal and foreign world views can be related to one another. Finally, in an atmosphere of mutual trust, learners can dare to mutually immerse themselves in the worlds of faith and identity of the respective other, a "learning in/through". In a sincere encounter of this kind, harmonized post-identitarian worldviews can emerge that facilitate togetherness as well as common action-guiding beliefs and values [11].

As we have seen in the case study, learners were able to harmonize their worldviews in the investigated environment, focusing on common values without giving up their own points of view. In their common vision of the future they achieved a sustainable common position with regard to seeming opposites such as technology vs. nature, labor market vs. personality orientation of education, paradise concepts of the Bible vs. the Quran (see Section 3.2). This can be a basis for good encounters between different cultures and religions both in school and everyday life.

\subsection{Reflective Inclusion as a Desideratum for Teacher Education}

Finally, the above perspectives (see Sections 4.1-4.3) make it apparent that dealing with worldview diversity leads to complex teaching/learning situations for which teachers must be adequately prepared. In particular, they should be trained to distinguish between personal and organized worldviews. As we have seen, apparently incompatible worldviews such as those of Islam and Christianity do not necessarily have to contradict each other at the level of the derived personalized worldviews. For example, the ideas of paradise introduced by the different learners were not controversial (see Section 3.2).

In order to gain further insights in the field of Reflective Inclusion, the data collected at Münsterlandschule (see Section 2) were discussed as part of a university course on worldview diversity for students of the teaching profession in the winter semester 2016/2017. Our aim was to immediately implement the empirical findings of the abovementioned study (see Section 3) in teacher education at university. The students sifted through the material and discussed their expectations and observations. On the basis of an initial evaluation of this group discussion, the following key points for dealing with worldview diversity in the context of teacher education can be formulated.

Teachers should be able to understand which worldviews expressed by learners are actually part of organized worldviews and which are individual readings of the learners. For example, disruptions coming from a learner who observes fasting rules for religious reasons cannot be generalized and attributed to all learners with the same religion. It is quite conceivable that different learners interpret orthopraxy in varying degrees of rigor. In the sense of the concept of Reflective Inclusion (see Section 1.2.2) a positive knowledge of organized worldviews protects teachers from forming prejudices against certain political or religious groups. In this sense, (self-)reflection is a crucial dimension of the professional work of teachers, especially in the context of inclusive diversity-sensitive education. To this end, embedding reflective inclusion in teacher education is an important requirement, if we want the aforementioned methods and didactics to work.

Author Contributions: J.B. and T.B. conceived and designed the experiments; T.B. performed the experiments; J.B. and T.B. analyzed the data; J.B. contributed reagents and materials, T.B. the analysis tools; J.B. and T.B. wrote the paper.

Funding: This study was conducted as part of the project "Dortmunder Profil für inklusionorientierte Lehrer/-innenbildung DoProfiL" (Dortmund Profile for Inclusion-Oriented Teacher Education). The Ministry of Education and Research of the Federal Republic of Germany is supporting this project as part of the "Qualitätsoffensive Lehrerbildung" (Quality Offensive for Teacher Education).

Conflicts of Interest: The authors declare no conflict of interest. 


\section{References}

1. Bartz, J. Jugendpastoral auf neuen Wegen: Der XXVIII. Weltjugendtag in Rio de Janeiro und sein Beitrag für die Kirche vor Ort; LIT Verlag: Münster, Germany, 2017.

2. Roebben, B. Einander in der Fremdheit begegnen. Möglichkeiten und Grenzen einer Spiritual Learning Community. In Anerkennung in religiösen Bildungsprozessen. Interdisziplinäre Perspektiven. Diskursschrift für Martin Jäggle; Krobath, T., Lehner-Hartmann, A., Polak, R., Eds.; V\&R Unipress: Wien, Austria, 2013; pp. 149-164.

3. Roebben, B. Living and Learning in the Presence of the Other. Defining Religious Education Inclusively. Int. J. Inclusive Educ. 2012, 16, 1175-1187. [CrossRef]

4. Bakker, C.; Montessori, N.M. Complexity in Education. From Horror to Passion; Sense Publishers: Rotterdam, The Netherlands, 2016.

5. Rose, D.H.; Meyer, A. Teaching Every Student in the Digital Age: Universal Design for Learning; Association for Supervision and Curriculum Development: Alexandria, Virginia, 2002.

6. Budde, J.; Hummrich, M. Reflexive Inklusion. Zeitschrift Für Inklusion. 2014. Available online: https: / / www.inklusion-online.net/index.php/inklusion-online/article/view/193 (accessed on 15 July 2018).

7. Hinz, A. Von der Integration zur Inklusion—terminologisches Spiel oder konzeptionelle Weiterent-wicklung? Zeitschrift für Heilpädagogik 2002, 53, 354-361.

8. Grosche, M. Was ist Inklusion? Ein Diskussions- und Positionsartikel zur Definition von Inklusion aus Sicht der empirischen Bildungsforschung. In Inklusion von Schülerinnen und Schülern mit sonderpädagogischem Förderbedarf in Schulleistungserhebungen; Kuhl, P., Stanat, P., Lütje-Klose, B., Gresch, C., Pant, H., Prenzel, M., Eds.; Springer VS: Wiesbaden, Germany, 2015; pp. 17-39.

9. Mace, G.; Hardie, J.; Place, J.P. Accessible Environments: Toward Universal Design; The Center for Universal Design: Raleigh, NC, USA, 1996.

10. Dannenbeck, C.; Dorrance, C. Inklusion als Perspektive (Sozial)pädagogischen Handelns-Eine Kritik der Entpolitisierung des Inklusionsgedankens. Zeitschrift für Inklusion. 2009. Available online: http: / / bidok.uibk.ac.at/library/inkl-02-09-dannenbeck-inklusion.html (accessed on 15 July 2018).

11. Bartz, J.; Delucchi Danhier, R.; Mertins, B.; Schüppel, K.; Welzel, B.; Zimenkova, T. Auf dem Weg zur Neuverortung: Sprache, Objektkultur und Religion im transkulturellen Deutschland. In Dortmunder Profil für inklusionsorientierte Lehrerinnen- und Lehrerbildung; Hußmann, S., Welzel, B., Eds.; Waxmann: Münster, Germany, 2018; pp. 179-194.

12. Roebben, B. Schulen für das Leben. Eine kleine Didaktik der Hoffnung; Calwer Verlag: Stuttgart, Germany, 2016.

13. Roebben, B. Religionspädagogik der Hoffnung: Grundlinien Religiöser Bildung in der Spätmoderne; LIT Verlag: Münster, Germany, 2011.

14. Van der Kooij, J.C. Worldview and Moral Education: On Conceptual Clarity and Consistency in Use. Ph.D. Thesis, Vrije Universiteit, Amsterdam, The Netherlands, 14 November 2016.

15. Meyring, P. Qualitative Inhaltsanalyse: Grundlagen und Techniken; Beltz: Weinheim, Germany, 2010.

16. Tuggener, D. Incremental Coreference Resolution for German. Ph.D. Thesis, University of Zurich, Zurich, Switzerland, 13 July 2016.

17. Blei, D.M.; Ng, A.Y.; Jordan, M.I. Latent Dirichlet Allocation. J. Mach. Learn. Res. 2003, 3, 993-1022.

18. Hoffmann, L. Deutsche Grammatik. Grundlagen für Lehrerausbildung, Schule, Deutsch als Zweitsprache und Deutsch als Fremdsprache; Erich Schmidt Verlag: Berlin, Germany, 2016.

19. Bubenhofer, N.; Müller, N.; Scharloth, J. Narrative Muster und Diskursanalyse: Ein datengeleiteter Ansatz. Zeitschrift für Semiotik 2013, 35, 419-444.

(C) 2018 by the authors. Licensee MDPI, Basel, Switzerland. This article is an open access article distributed under the terms and conditions of the Creative Commons Attribution (CC BY) license (http:/ / creativecommons.org/licenses/by/4.0/). 